\title{
Mechanical and Morphostructural Characteristics of Composite Materials Performed by Recycling Mixed Waste of Plastic and Paper
}

\author{
ROMEO CRISTIAN CIOBANU ${ }^{1}$, GHEORGHE BATRINESCU², GEORGE ANDREI URSAN ${ }^{3}$, ALINA RUXANDRA CARAMITU4, \\ VIRGIL MARINESCU4, ADRIANA MARIANA BORS ${ }^{5 *}$, IOSIF LINGVAY ${ }^{4}$ \\ 1.SC ALL GREEN SRL, 8 George Cosbuc, 700470, Iasi, Romania \\ 2.INCD ECOIND, 71-73 Drumul Podul Dambovitei, 060652 Bucharest, Romania \\ 3.Technical University Gheorghe Asachi of Iasi, 53A Dimitrie Mangeron Blvd., 700050, Iasi, Romania \\ 4.National Institute for Research and Development in Electrical Engineering INCDIE ICPE-CA, 313 Splaiul Unirii, 030138, Bucharest, \\ Romania \\ 5.ICPE-SA, 313 Splaiul Unirii, 030138, Bucharest, Romania
}

\begin{abstract}
In order to evaluate the possibility of reuse of some mixed waste from plastic and paper, composite samples of both HDPE and PP basis were made with different filler contents of crushed postage envelope waste. From the morphostructural characterization (SEM images) of the samples obtained it was observed that the HDPE and PP samples had had a homogeneous single-phase structure in contrast to the composite samples with filler from mixed plastic and paper waste. The latter, have a biphasic heterogeneous structure in which the cellulose particles are uniformly distributed. Determinations performed through the dielectric spectroscopy technique indicated that the cellulose content of the composite samples leads to a systematic increase of the dielectric losses (up to about 40\% for the HDPE samples, respectively about $30 \%$ for the samples with PP), the increases being in direct correlation with the cellulose content of the composite.Mechanical determinations have shown that the average values of tensile strength recorded on the achieved samples, systematically decrease at the increase in the chips content of the samples decreases up to $10 \%$ at an addition up to $15 \%$ chips from the waste are explained by the substantially lower mechanical strength of waste paper than that of the HDPE, respective PP.
\end{abstract}

Key words: waste, composite, HDPE, PP, filler, paper, dielectric loss, tensile strength

In the perspective of a strong and sustainable development, the issue of adequate waste processing is a priority.

In this context, the recovery and reuse of waste materials is of particular importance, thus contributing to the reduction of environmental footprint, both bypreventing environmental pollution (including persistent pollutants [1, 5]) and preserving non-renewable natural resources (metals, hydrocarbons etc.). Polymeric materials during operation, under the action of stress factors specific to the operating environment, suffer a series of ageing processes by which functional characteristics degrade significantly [6-13]. In practice, waste containing polymeric material shows a great diversity (inseparable mixtures obtained from various polymers with or without metals, paper, wood, etc.), which makes their recovery and reuse by established methods impossible (involving the separation of each component in part).

On the other hand, based polymer nanocomposite materials with various metallic and non-metallic fillers can exhibit a number of remarkable functional characteristics in various applications [14], such as: elasticity [15-18], mechanical strength [19] heating, low permeability for gases [20-22], flame-burning [23, 24], electrical characteristics [25, 26], biodegradability [27-30], etc.

In this context, the aim of the work is to obtain and characterize composite thermoplastic materials with filler of plastic and paper waste.

\section{Experimental part}

Waste of postage envelopes type with a content of about $50 \%$ polyethylene and $50 \%$ paper, were shredded with a rotary mill manufactured by VEB NOSSENER Maschinenbau. veb nossener maschinenbau.
Chips obtained (fig.1) were used as a filler to obtain of polyethylene and polypropylene thermoplastic composite.
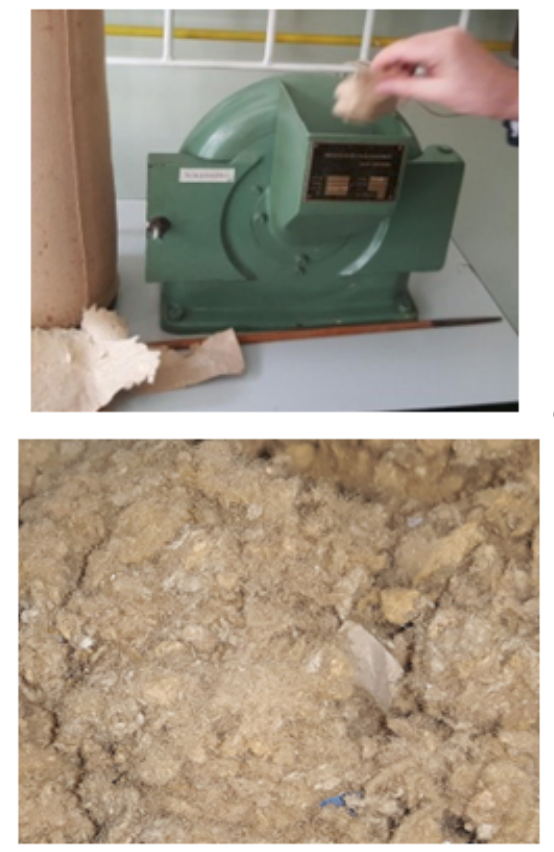

Fig. 1. Appearance of chips obtained by crushing of postal envelope waste from paper and plastic

The chips were blended in various proportions by extrusion with powder of HDPE, of ELTEX type A3180PN1852 [31], respective polypropylene granules of Tipplen H 318 [32] type.

The extrusion of the chip mixes from HDPE waste, respective PP powders, was carried out in a laboratory extruder (Brabender-KETSE).

The working parameters on the extruder were:

\footnotetext{
* email: adrianambors@gmail.com, Phone +40 773917319
} 
- extruder screw speeds of $45 \mathrm{rpm}$;

- screw speed of hopper funnel: $700 \mathrm{rpm}$;

- the temperatures on the heating zones of the extruder are shown in Table 1.

Table 1

TEMPERATURES ON THE HEATING ZONES OF THE EXTRUDER

\begin{tabular}{|c|c|c|c|c|c|c|}
\hline \multirow{2}{*}{ Zone } & 1 & 2 & 3 & 4 & 5 & 6 \\
\hline & \multicolumn{6}{|c|}{ Temperature $\left[{ }^{\circ} \mathrm{C}\right]$} \\
\hline HDPE & 165 & 170 & 175 & 180 & 185 & 195 \\
\hline $\mathrm{PP}$ & 170 & 175 & 180 & 185 & 190 & 220 \\
\hline
\end{tabular}

The amount of chips from waste samples obtained (composite granules) are shown in Table 2.

Table 2

COMPOSITION AND CODING OF SAMPLES OBTAINED BY EXTRUSION

\begin{tabular}{|c|l|}
\hline Samples cod & \multicolumn{1}{|c|}{ Compozition } \\
\hline$M 1$ & HDPE powder \\
\hline$M 2$ & PP granules \\
\hline$M 3$ & HDPE $+5 \%$ chips from waste \\
\hline$M 4$ & $\mathrm{HDPE}+10 \%$ chips from waste \\
\hline$M 5$ & $\mathrm{HDPE}+15 \%$ chips from waste \\
\hline$M 6$ & $\mathrm{PP}+5 \%$ chips from waste \\
\hline$M 7$ & $\mathrm{PP}+10 \%$ chips from waste \\
\hline$M 8$ & $\mathrm{PP}+15 \%$ chips from waste \\
\hline
\end{tabular}

In order to characterize the thermoplastic composites obtained from the $\mathbf{M 1 - M 8}$ granules, discs with a diameter of $30 \mathrm{~mm}$ and a thickness of $2.5 \mathrm{~mm}$ (for morpho-structural and dielectric characterizations) (Dr Boy-Germany injection machine) and bars with the section of $2.5 \times 10$ $\mathrm{mm}$, with $100 \mathrm{~mm}$ long (to determine breaking strength) were injected.

The closing force of the injection mold was $350 \mathrm{kN}$, the temperatures of the injection machine heating zones are shown in Table 3.

Morpho-structural characterization of the obtained samples was performed by SEM microscopy with an equipment INCA Energy 250 energy dispersive spectrometer (EDS) - Oxford Instruments belonging Auriga (Zeiss) field emission scanning electron microscope (FESEM).

Table 3

TEMPERATURES ON THE HEATING ZONES OF THE INJECTION MACHINE

\begin{tabular}{|c|c|c|c|c|c|}
\hline \multirow{2}{*}{ Zone } & $\mathbf{5}$ & $\mathbf{4}$ & $\mathbf{3}$ & $\mathbf{2}$ & $\mathbf{1}$ \\
\cline { 2 - 6 } & \multicolumn{5}{|c|}{ Temperature [ $\left.{ }^{\circ} \mathrm{C}\right]$} \\
\hline HDPE & 200 & 195 & 185 & 175 & 165 \\
\hline PP & 230 & 225 & 210 & 195 & 170 \\
\hline
\end{tabular}

Characterization of the dielectric behavior of the obtained composites - determination of dielectric loss tg $\delta$ at $20 \pm 2^{\circ} \mathrm{C}$ by dielectric spectroscopy technique with 1296 Dielectric interface / AMTEK - Solartron Analytical.

Determination of tensile strength by traction was performed with equipment MRCLAB - UTM 65B Universal Test Machine.

\section{Results and discussions}

The results of SEM determinations are shown in Figure 2 (injected samples based on HDPE) and in Figure 3 (injected samples based on PP).

The comparative analysis of the Figures 2 and 3 shows that the reference samples (M1 and M2 - from HDPE and pure PP) have a homogeneous (monophasic/single phase) structure and shows the imprint of the injection mold (inclined stripes).

On the samples with filler from paper waste, a heterogeneous (biphasic) structure is observed where the



Fig.2. SEM image of injected HDPE samples: a) - M1; b) M3; c) - M4; d) - M5



Fig. 3. SEM image of injected PP samples: a) - M2; b) - M6;

$$
\text { c) - M7; d) - M8 }
$$

paper particles are homogeneously distributed and well embedded in the polymer - the samples are no gaps.

The results of determinations by the dielectric spectroscopic technique are shown in Figure 4 for both samples based on HDPE (a) and PP (b), for various contents with filler from paper waste.

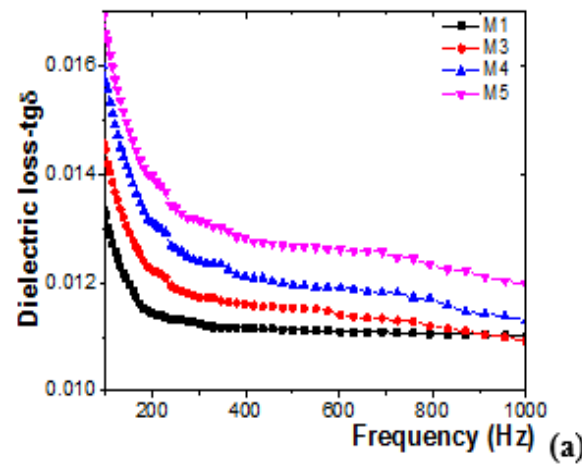

Fig.4. Evolution of dielectric losses according to the



frequency of investigated

polymer samples:

a) - based on HDPE;

b) - based on PP 


\begin{tabular}{|c|c|c|c|c|c|c|c|}
\hline \multirow{2}{*}{ Sample } & \multicolumn{7}{|c|}{ The tensile strength of samples [MPa] } \\
\hline & I & 2 & 3 & 4 & 5 & Average & $\Delta_{\max }$ \\
\hline \multicolumn{8}{|l|}{ based on HDPE } \\
\hline M1-reference & 5.11 & 5.12 & 5.13 & 5.11 & 5.12 & 5.118 & 0.02 \\
\hline $\mathrm{MB}-5 \%$ chips & 5.04 & 5.03 & 5.05 & 5.03 & 5.05 & 5.040 & 0.02 \\
\hline M4 -10\% chips & 4.86 & 4.88 & 4.87 & 4.88 & 4.88 & 4.874 & 0.02 \\
\hline M5 - $15 \%$ chips & 4.66 & 4.63 & 4.64 & 4.66 & 4.65 & 4.648 & 0.03 \\
\hline \multicolumn{8}{|l|}{ based on PP } \\
\hline $\mathrm{M} 2$ - reference & 6.42 & 6.43 & 6.41 & 6.43 & 6.42 & 6.422 & 0.02 \\
\hline M6 - 5\% chips & 6.28 & 6.30 & 6.29 & 6.30 & 6.29 & 6.292 & 0.02 \\
\hline M7 - 10\% chips & 6.06 & 6.09 & 6.09 & 6.07 & 6.08 & 6.078 & 0.03 \\
\hline M8 - $15 \%$ chips & 5.78 & 5.77 & 5.76 & 5.79 & 5.80 & 5.780 & 0.04 \\
\hline
\end{tabular}

Table 4

THE TENSILE STRENGTH OF THE AHIEVED SAMPLES
By comparative analysis of Figures $4 \mathrm{a}$ ) and b) it is observed that in the range of $100-1000 \mathrm{~Hz}$ the dielectric losses on the reference samples (M1 - pure HDPE, respective $\mathbf{M} 2$ - PP pure) show approximately identical values and evolutions.

It is also noted that the cellulose content of the samples with paper filler (mixed chips from paper and plastic waste) leads to a systematic increase of the dielectric losses (up to about $40 \%$ for HDPE samples, or about $30 \%$ in the PP samples), the increases being in direct correlation with the cellulose content of the composite.

Thus, the increase in cellulose content also increases the dielectric losses.

This behavior can be explained by the content of polar -OH (hydroxyl) groups of cellulose which leads to increased dielectric losses.

The results of the mechanical strength measurements of the obtained composite samples, respectively the tensile strength values obtained, as well as the maximum differences $\Delta_{\text {max }}$ recorded between the five samples in each sample are shown in table 4.

Data analysis of Table 4 shows that the tensile strength of the samples based on PP are systematically higher by about 25\% than those based on HDPE.

It is also noted that the maximum tensile strength differences recorded between the five samples in each sample are $0.02 \mathrm{MPa}$ for samples with low content of chip from mixed waste of paper and plastic.

The value of $0.03 \mathrm{MPa}$ was recorded on sample M5 (15\% chips in HDPE) and M7 (10\% chips in PP) and the maximum dispersion of $0.04 \mathrm{MPa}$ was recorded only on sample M8 ( $15 \%$ chips in PP).

. It can be noticed that the average values of the tensile strength recorded, systematically decrease at the increase in the chips content of the sample.

The tensile strength evolution of the samples based on HDPE and on PP depending on the chips content from mixed waste of paper and plastic, is illustrated in Figures 5 and 6.

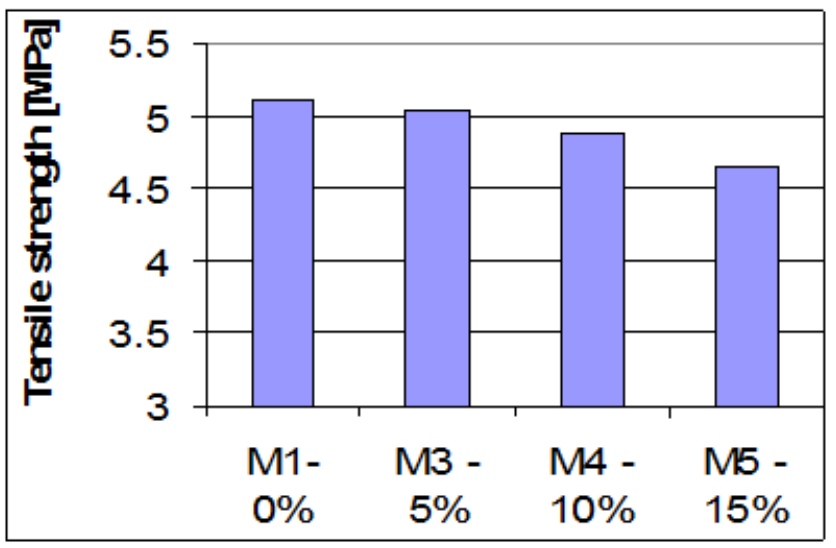

Fig. 5. Evolution of the tensile strength of samples based on HDPE depending on the chips content from waste of paper and plastic



Fig. 6. Evolution of the tensile strength of samples based on HDPE depending on the chips content from waste of paper and plastic

Losses of the tensile strengths (decrease of the mean values obtained on the average value determined on HDPE, respective PP pure) of the composites achieved depending on the chips content from waste of paper and plastic are shown in figures 7 and 8.

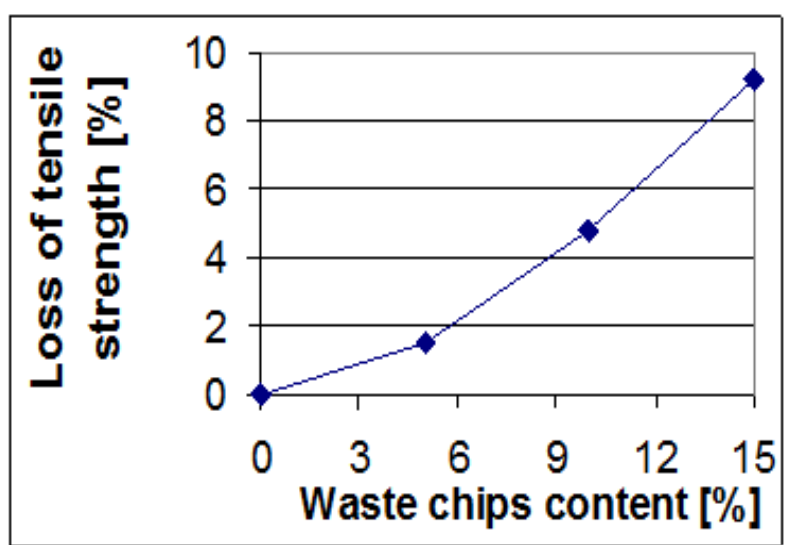

Fig. 7. Losses of tensile strength of composites based on HDPE depending on the chips content from waste of paper and polymer

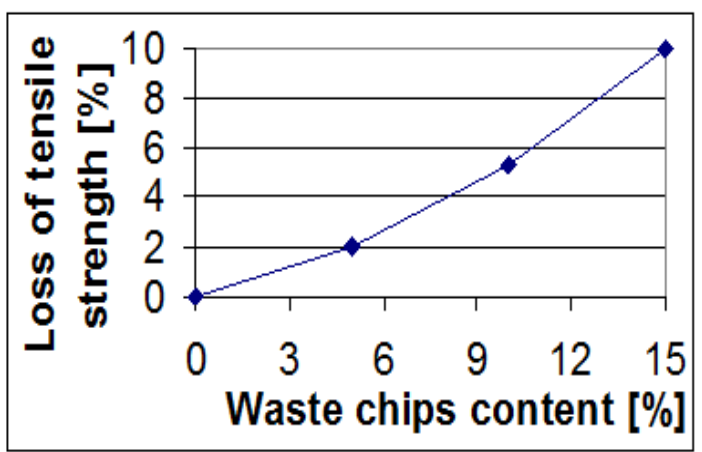

Fig. 8. Losses of tensile strength of composites based on PP depending on the chips content from waste of paper and polymer 
By comparing Figures 5 with 6 and Figures 7 with 8 , it is noted that the addition of chips from waste of the paper and polymer has a similar effect in both samples based on HDPE and on PP. This aspect also leads to a $10 \%$ tensile strength with an addition of up to $15 \%$ chips. This behavior to the mechanical stress of the composite samples can be explained by the tensile strength of the paper from chips substantially smaller than the HDPE, respective PP.

\section{Conclusions}

In order to evaluate the possibility of reuse of some mixed waste from plastic and paper, composite samples were made on both HDPE and PP basis with various filler contents of crushed postal envelope waste. From morphostructural, mechanical and dielectric characterization of the composite samples obtained by extrusion and injection, it was found that:

-comparative SEM images recorded on the samples show a monophasic/single phase homogeneous structure in HDPE and pure PP samples and a biphasic heterogeneous structure for composites with filler from mixed waste of plastic and paper;

-the cellulose content of the samples with paper filler ( mixed chips from paper and plastic waste) leads to a systematic increase of the dielectric losses (up to about $40 \%$ for HDPE samples, or about $30 \%$ in the PP samples), the increases being in direct correlation with the cellulose content of the composite - aspect explicable by including polar hydroxyl groups $(-\mathrm{OH})$ in the nonpolar polymer of cellulose filler

-the average values of the tensile strength recorded on the samples are systematically decreasing as the content of the chips in the samples increases. The decreases of up to $10 \%$ at an addition up to $15 \%$ chips from waste are explained by the much lower mechanical resistance of paper from waste than of HDPE, respective PP.

These findings lead to the conclusion that mixed waste of paper and plastic can be used to achieved composite material based on HDPE or PP for applications that do not require special mechanical and electrical performance.

Acknowledgment: This work was financially supported by the project REAVPLAH, Competitiveness Operational Programme 2014-2020, Project Promoting, identifying and implementing partnerships for knowledge transfer in industrial ecology SMIS 2014 + 105581, Subsidiary contract nr. 15351/13.09.2017 and the contract POC type D, No.11384/ 18.06.2018 ("ECO-NANO-ECO").

\section{References}

1.STEFAN, M., BORS, A.-M., STEFAN, D.S., RADU, I.A.S., MARINESCU, C., Rev. Chim. (Bucharest), 68, no. 12, 2017, p. 2804.

2.BORS, A.M., MEGHEA, I., MIHALY, M., MUNTEANU, C., BADEA, M., International Multidisciplinary Scientific GeoConference Surveying Geology and Mining Ecology Management, SGEM 2015, vol. 1 (4), 2015, p. 533.

3.MEGHEA, I., BORS, A.G., MUNTEANU, G.-V., MUNTEANU, C., BORS, A.-M., International Multidisciplinary Scientific GeoConference Surveying Geology and Mining Ecology Management, SGEM 2013, vol.1, 2013, p. 1113.
4.BORS, A.M., MEGHEA, I., NICOLESCU, A.M., BORS, A.G., 12th International Multidisciplinary Scientific GeoConference and EXPO Modern Management of Mine Producing, Geology and Environmental Protection, SGEM 2012, vol. 5, 2012, p.891.

5.NEAMTU, S., BORS, A.M., STEFAN, S., Rev. Chim. (Bucharest), 58, no. 9, 2007, p. 938.

6.RUS, T., BORS, A.M., CARAMITU, A.R., LINGVAY, I., VAIREANU, D.I., Mat. Plast., 55 , no. 2, 2018, p. 167.

7.VARGA, E., FORTUNA, L., LINGVAY, D., BORS, A.M., NICULA, N.O., LINGVAY, I., Mat. Plast, 55 , no. 3, 2018, p. 320.

8.RUS, T., LINGVAY, I., CARAMITU, A.R., BORS, A.M., VAIREANU, D.I. Mat. Plast., 54, no. 4, 2017, p. 720.

9.RADERMACHER, L., BORS, A.-M., LINGVAY, D., NICULA BUTOI, N.O., VOINA, A., MARIN, D., EEA - Electrotehnica, Electronica, Automatica, vol. 66 (4), 2018, p. 66.

10.BORS, A.M., BUTOI, N., CARAMITU, A.R., MARINESCU, V., LINGVAY, I., Mat. Plast, 54, no. 3, 2017, p. 447.

11. VOINA, A., NITÃA, P., LUCHIAN, A.-M., LINGVAY, D., BUTOI, N., BORS, A.-M., LINGVAY, I., EEA - Electrotehnica, Electronica, Automatica, vol. 65 (2), 2017, p. 60.

12.LUNGULESCU, E.M., LINGVAY, I., UNGUREANU, L.C., RUS, T., BORS, A.M., Mat. Plast, 55, no. 2, 2018, p. 201.

13. RUS, T., CARAMITU, A.R., UNGUREANU, L.C., MARINESCU, V., BORS, A.M., VAIREANU, D.I., Mat. Plast, 55, no. 1, 2018, p. 28.

14. SUPRAKAS, S.R., MASAMI, O, Prog. Polym. Sci., vol. 28, 2003, p. 1539.

15.MASAMI, O., Prog. Polym. Sci., p. 1630.

16.MARK, J.E., editors., MRS Symposium Proceedings, Pittsburgh, vol. 17, 1990, p. 45.

17.GIANNELIS, E.P, Adv. Mater., vol. 8, 1996, p. 29.

18.GIANNELIS, E.P., KRISHNAMOORTI, R., MANIAS, E., Adv Polym. Sci., vol. 138, 1999, p. 107.

19.VAIA, R.A., PRICE, G., RUTH, P.N., NGUYEN, H.T., LICHTENHAN, J., Appl. Clay. Sci., vol. 15, 1999, p. 67.

20.GIANNELIS, E.P., Appl. Organomet. Chem., vol. 12, 1998, p. 675.

21.BISWAS, M., SINHA, R.S., Adv. Polym. Sci., vol. 155, 2001, p. 167.

22. BHARADWAJ, R.K., Macromolecules, vol. 34, 2001, p. 1989.

23.GILMAN, J.W., Appl. Clay. Sci., vol. 15, 1999, p. 31.

24.GILMAN, J.W., KASHIWAGI, T., LICHTENHAN, J.D., Sample J., vol. 33, 1997, p. 40.

25.CARAMITU, A.-R., MITREA, S., MARINESCU, V., URSAN, G.-A., ARADOAIE, M., LINGVAY, I., Mat. Plast., 56, no. 1, 2019, p. 103.

26.CARAMITU, A-R., MARINESCU, V., MITREA, S., ARADOAIE, M., URSAN G.-A., Electrotehnica, Electronica, Automatica (EEA), vol. 67 (1), 2019, p. 61.

27. RUS, T., RADU, E., LINGVAY, I., LINGVAY, M., CIOBOTEA-BARBU, O.C., CAMPUREANU, C., BENGA, F.M., LAZAR, G.-C., VAIREANU, D.-I., U.P.B. Sci. Bull., Series B, vol. 79 (4), 2017, p. 167.

28.LINGVAY, I., FORTUNA, L., VARGA, E., BORS, A.-M., NICULA BUTOI, N.O., LINGVAY, D., EEA - Electrotehnica, Electronica, Automatica, vol. 66 (4), 2018, p. 52.

29.CARAMITU, A., BUTOI, N., RUS, T., LUCHIAN, M.A., MITREA, S., Mat. Plast., 54 , no. 2, 2017, p. 331.

30.BOURBIGOT, S., LEBRAS, M., DABROWSKI, F., GILMAN, J.W., KASHIWAGI, T., Fire Mater, vol. 24, 2000, p. 201.

31. $* * *$ https://www.ineos.com $/ \mathrm{nl} / \mathrm{show}$-document $/$ ?grade= A3180PN1852\&bu $=$ INEOS+0+\%2526+P+Europe \&document Type $=$ Technical + Data + Sheet $\&$ docLanguage $=$ EN\&version $=\mathrm{fc} 678 \mathrm{add} 30$ e61f25fff209e49d34d087

32.*** https://www.granulat.com.pl/media/pdf/tipplen\%20h\%20318.pdf

Manuscript received: 8.04 .2019 